\title{
Listeria monocytogenes Virulence, Antimicrobial Resistance and Environmental Persistence: A Review
}

\author{
Lavious Tapiwa Matereke ${ }^{1,2, *}$ and Anthony Ifeanyi Okoh 1,2,*(D) \\ 1 SAMRC Microbial Water Quality Monitoring Centre, University of Fort Hare, Alice 5700, South Africa \\ 2 Applied and Environmental Microbiology Research Group, Department of Biochemistry and Microbiology, \\ University of Fort Hare, Alice 5700, South Africa \\ * Correspondence: 200909597@ufh.ac.za (L.T.M.); AOkoh@ufh.ac.za (A.I.O.)
}

Received: 5 May 2020; Accepted: 20 June 2020; Published: 30 June 2020

\begin{abstract}
Listeria monocytogenes is a ubiquitous opportunistic pathogen responsible for the well-known listeriosis disease. This bacterium has become a common contaminant of food, threatening the food processing industry. Once consumed, the pathogen is capable of traversing epithelial barriers, cellular invasion, and intracellular replication through the modulation of virulence factors such as internalins and haemolysins. Mobile genetic elements (plasmids and transposons) and other sophisticated mechanisms are thought to contribute to the increasing antimicrobial resistance of L. monocytogenes. The environmental persistence of the pathogen is aided by its ability to withstand environmental stresses such as acidity, cold stress, osmotic stress, and oxidative stress. This review seeks to give an insight into L. monocytogenes biology, with emphasis on its virulence factors, antimicrobial resistance, and adaptations to environmental stresses.
\end{abstract}

Keywords: Listeria monocytogenes; virulence; biofilm; antimicrobial resistance; environmental stress

\section{Introduction}

Listeria species are ubiquitous Gram-positive rods found in different environmental niches. Among the species in the genus Listeria, Listeria monocytogenes and Listeria ivanovii, are pathogenic, with the former being a human foodborne pathogen causing listeriosis and associated with other human ailments such as bacteremia, encephalitis, and sepsis [1]. L. monocytogenes was proven as the causative agent of listeriosis following an outbreak in 1989, but the pathogen had been detected as early as 1924 [2]. It is a psychrotolerant pathogen, capable of growing at different temperatures $\left(1-45^{\circ} \mathrm{C}\right)$, but the optimum temperature ranges from 30 to $37^{\circ} \mathrm{C}$ [3]. The pathogen is proficient in switching between saprophytism and virulence, depending on the environmental setting [4].

Infection by L. monocytogenes results in either non-invasive gastrointestinal listeriosis among immunocompetent individuals or invasive listeriosis among immunocompromised people $[5,6]$. Invasive listeriosis leads to abortion in pregnant women and meningitis in immunocompromised individuals [7]. During the 2017-2018 listeriosis outbreak in South Africa, a 42\% fatality rate was recorded, with more than 1000 laboratory-confirmed cases, and the most infected were infants and pregnant women [8]. Individuals on medications that minimize gastric acidity as well as chronic renal failure and cirrhosis patients are also at risk [9]. Also, Listeria-related urinary tract infections were reported in an incident wherein L. monocytogenes was detected in urine samples [10].

The major transmission route to humans is contaminated food, mainly ready-to-eat foods [11]. Irrigation waters and agricultural soils also harbor multidrug-resistant $L$. monocytogenes that is likely to be disseminated to agricultural fresh produce, posing a threat to food safety [12]. Poor hygiene practices and inadequate implementation of standard sanitation operating procedures (SSOPs) in the food processing industry have led to listeriosis outbreaks [13]. Furthermore, the pathogen easily forms 
biofilms and persister cells on surfaces, which may not be easily removed by standard sanitation protocols [14]. L. monocytogenes can be found concealed in difficult-to-clean tools such as slicers, food transport vehicles, and refrigeration units [14]. The pathogen also inhabits the gastrointestinal tract of humans and animals; hence, unhygienic practices may facilitate its dispersal through the contamination of food and equipment [2].

Adaptations of the pathogen to environmental stresses and pre-exposure adaptation to sublethal concentrations of antimicrobial agents have subsequently contributed to its antimicrobial resistance $[15,16]$. Therefore, understanding the principal mechanisms governing $L$. monocytogenes survival, virulence, antimicrobial resistance, and persistence in adverse environmental conditions is vital for the management and control of this pathogen, as well as the development of novel antimicrobial agents against it.

\section{Virulence Factors}

\subsection{Hemolysins}

Production of hemolysins by Listeria species was first demonstrated by Harvey and Faber in 1941 using L. monocytogenes [17]. It was later shown that this hemolysin is an ortholog of streptolysin O (SLO) from Streptococcus pyogenes and hence was named listeriolysin O (LLO) [18]. Encoded by the hly gene, listeriolysin $\mathrm{O}$ is a $\mathrm{pH}$-controlled toxin that has been shown to promote infection from several niches within the host, mainly the extracellular environment, phagosome, and cytosol [19]. In the extracellular environment, LLO facilitates the internalization of L. monocytogenes into phagosomes by creating membrane perforations into the host cell [20]. LLO induces ion-permeable pores on the plasma membrane which allow calcium influx into the host cells, and this promotes the invasion of Hep-2 epithelial cells by L. monocytogenes [21]. LLO also mediates apoptosis of T cells, lymphocytes, and dendritic cells [22]. Within the phagosome, LLO induces pore formation to facilitate bacterial escape from host phagosomes (lysis) and aids the pathogen in intracellular replication [23]. The membrane lesions created during the process enable the passage of phospholipases which hydrolyze membrane phospholipids, resulting in complete breakdown of the plasma membrane [17]. LLO also suppresses reactive oxygen species (ROS) released by the phagocyte in response to infection, but the mechanism is yet to be understood [24]. In the cytosol, LLO prompts host histone modifications by deacetylation of $\mathrm{H} 4$ and dephosphorylation of Ser10 in H3 histones [25]. It also enhances infection by promoting the degradation of host proteins, though the mechanisms are yet to be understood [19]. In one study, treatment of the host proteome with LLO reduced the abundance of 149 proteins [26]. LLO causes mitochondrial fragmentation by inducing calcium influx through the ion-permeable pores on the plasma membrane [27]. However, overexpression of LLO can expose the pathogen to host immune defenses. This is a result of membrane lesions which lead to apoptosis and demolition of the pathogen's intracellular niche, thus exposing the pathogen to the circulating defense machinery [28,29]. Host proteasomal degradation of LLO can be one mechanism employed to limit its activity within the host cytosol [28]. Another study also revealed in vitro aggregation and denaturation of LLO at $37^{\circ} \mathrm{C}$ and neutral $\mathrm{pH}$, suggesting that this could be another regulatory mechanism for LLO activity within the host cytosol [30].

\subsection{Phospholipases}

L. monocytogenes secretes phosphatidylinositol-specific phospholipase C (PI-PLC or PLC-A) encoded by the $p l c A$ gene and non-specific phosphotidylcholine phospholipase C (PC-PLC or PLC-B) encoded by the $p l c B$ gene [31]. PLC-A (PI-PLC) aids the pathogen in exiting the phagosome into the cytosol [32]. Together with PC-PLC and LLO, PI-PLC also facilitates the pathogen's exit from the double-membrane vacuole formed upon cell-to-cell spread [33]. Both PI-PLC and PC-PLC aid L. monocytogenes in subverting autophagy-mediated clearance by inhibiting pre-autophagosomal maturation or target recognition by the degradative pathway [34]. Autophagy is the process through 
which host intracellular dysfunctional organelles are degraded and recycled [35]. Autophagy also targets invading pathogens and thus plays a role in innate immunity [35]. In one study, mutant L. monocytogenes strains incapable of expressing phospholipases were vulnerable to autophagy during macrophage infection [36].

PC-PLC is initially expressed as a zymogen which is then activated by a zinc metalloprotease under acidic environments [37]. It assists in vacuolar escape in times of LLO deficiency during its invasion of epithelial cells, and its activity is crucial for cell-to-cell spread [38]. PC-PLC dual enzymatic activity as a phospholipase and sphingomyelinase could be essential for L. monocytogenes dispersal inside the host [39]. PC-PLC is an essential pathogenicity factor contributing to L. monocytogenes murine cerebral listeriosis [40]. However, premature discharge of PC-PLC into the host cell cytosol can be lethal to L. monocytogenes; thus, the pathogen has a PC-PLC regulation mechanism for efficient pathogenicity [41]. A PC-PLC mutant exhibited low resistance against intracellular killing by neutrophils, suggesting PC-PLC may potentiate the action of neutrophils against L. monocytogenes [42]. L. monocytogenes regulates the activity of PC-PLC by increasing the $\mathrm{pH}$ within the double-membrane vacuole [41]. This inhibits the activity of the metalloprotease, resulting in an inactive PC-PLC [43].

\subsection{ActA}

Encoded by the actA gene, the protein actA enables actin recruitment and polymerization, resulting in actin-based intracellular motility in pathogenic Listeria species [17]. Polymerized actin close to the phagosome membrane possibly gains entry through listeriolysin-mediated pores, and its polymerization could widen the pores [44]. This results in phagosome disruption, promoting bacterial escape from the phagosome [44]. Actin propels L. monocytogenes to host cell membranes, resulting in elongated protrusions from the membrane (fibroids) encircling the bacteria and extending to adjacent cells which engulf the fibroids [17]. In epithelial cells, ActA camouflages the pathogen with host proteins, thus shielding it from autophagy [45]. Using a murine model, one study demonstrated that ActA is crucial for placental invasion by L. monocytogenes and facilitates its vertical dissemination to the fetus [46]. ActA facilitates aggregation in L. monocytogenes through uninterrupted ActA-ActA interactions, is involved in biofilm formation, and mediates intestinal colonization [47]. Results from one study demonstrated that actin-based intracellular motility facilitates the exit of the pathogen from autophagic membranes within the macrophage cytosol [48].

\subsection{Internalins}

Internalins are surface proteins encoded by genes which are associated with virulence in pathogenic Listeria species. Internalin A (InlA) and Internalin B (InlB), both encoded by the inlAB operon, were the first internalins to be characterized from L. monocytogenes [17]. E-cadherin and Met are the internalins' receptors, respectively, both located on host cell surfaces [49]. Internalins mediate the adhesion and internalization of the pathogen by host nonphagocytic cells [50]. InlA-mediated internalization is constrained to a limited population of epithelial cells, and InlB-mediated internalization targets various cells like hepatocytes and epithelial and endothelial cells [51]. Using an epidemic strain, one study demonstrated that InlB enhances infection of the liver and spleen by L. monocytogenes [52].

Internalins consist of a signal peptide at the $\mathrm{N}$-terminus and 22-amino acid leucin-rich-repeats (LRR) [53]. The N-terminal region alone is capable of enhancing bacterial penetration into permissive cells [54]. These LLR regions are responsible for protein-protein interactions and are present in both prokaryotic and eukaryotic cells, where they also facilitate adhesion [55]. Other pathogenic bacterial species also express LLR regions [50]. Interactions between Internalin A and E-cadherin are vital for traversing the placental and intestinal barriers [49]. The novel InlL facilitates L. monocytogenes attachment to abiotic surfaces and plays a role in biofilm establishment [56]. Internalin $\mathrm{K}$ recruits a major vault protein (MVP) that camouflages the pathogen, shielding it from autophagic recognition [57]. Other novel internalins (InlP1, InlPq, and InlP4) which contribute to the virulence of L. monocytogenes, have been reported [58]. 


\section{Antimicrobial Resistance}

\subsection{Horizontal Gene Transfer}

Listeria species are reportedly capable of exchanging resistance determinants with other bacterial species. The broad-host-range Streptococcus agalactiae plasmid IP501, which confers resistance against macrolides, lincosamides, chloramphenicol, and streptogramins, was reportedly transferrable to L. monocytogenes via conjugation $[59,60]$. The same plasmid was reportedly capable of replication within Listeria species and transference among different Listeria species as well as back to Streptococcus [61]. The antimicrobial resistance plasmid pAM Beta I (pAM $\beta 1$ ) was successfully transferred from Streptococcus faecalis to some L. monocytogenes isolates by conjugation [62]. In the same study, conjugates were found to replicate within the host and were transferrable among L. monocytogenes strains or back to Streptococcus faecalis. One study demonstrated conjugation of the tet(S) gene from Lactococcus garvieae, a fish pathogen, to L. monocytogenes [63]. The transposon Tn916 harboring the tet $(M)$ gene, originally discovered in Enterococcus faecalis, was demonstrated to be transferrable between Enterococcus faecalis and Listeria innocua and that it was capable of jumping from one host to the other among various Listeria species [64]. Another Tn916-like transposon, TnFO1, harbored by multidrug-resistant Enterococcus faecalis, was found to be transferred from Enterococcus. faecalis to some species, including Listeria innocua, via conjugation [65].

Plasmids and transposons are thought to mediate tetracycline resistance in Listeria species [66]. Tet $M$ genes discovered in two tetracycline-resistant L. monocytogenes isolates were analogous to the ones previously discovered in Staphylococcus aureus [67]. In the same study, TetM genes from the other two isolates had sequences that were closely related to those of a family of conjugative transposons (Tn916-Tn1545). The Tn916-Tn1545 family is closely related to SHGII, which harbors TetM genes in Enterococci.

\subsection{Persister Cells and Biofilm Formation}

One mechanism underlying the antimicrobial resistance in L. monocytogenes is the formation of persister cells and biofilms. Persisters are a fraction of the overall cell population that is in a dormant, non-dividing state, which enhances them to withstand bactericidal antibiotics and harsh environmental conditions [68]. Persister cells provide an endurance strategy to L. monocytogenes, which is transformed from bacilli to cocci during the transition [69]. The persister phenomenon probably contributes to L. monocytogenes survival against disinfectants and may shield the pathogen from the host defense system for longer periods, which explains the absence of listeriosis clinical symptoms several days after infection [68]. In one study, long-term-survival cells were extremely resistant to high temperatures and pressure stresses [69]. These persisters are also able to withstand preservatives used to control heat-resistant bacteria during food processing [70].

A biofilm is a population of bacterial cells attached to each other or a surface and enclosed by a self-produced matrix of extracellular polymeric substances (EPS) (proteins, polysaccharides, and extracellular DNA) [71]. The matrix is a nutrient reservoir, facilitates adhesion, acts as a protective barrier against heat and desiccation, heavy metals, ultraviolet rays, acids, and also inhibits the permeation of antimicrobial agents by restricting their diffusion potentials [72,73]. Persistent L. monocytogenes strains were found to have significantly better biofilm-forming capabilities than non-persistent ones [74]. Biofilms are reportedly behind the pathogen's increased tolerance to quaternary ammonium compounds due to changes in membrane fluidity [75]. Biofilms can also protect $L$. monocytogenes from the action of biocides, but the underlying mechanism of biocide protection is yet to be clarified [76].

\subsection{Efflux Pumps}

The minimum susceptibility of L. monocytogenes to antimicrobial agents is also attributed to some efflux pumps. The Lde efflux pump was found to be associated with fluoroquinolones resistance in 
L. monocytogenes isolated from listeriosis patients [77]. In the same study, the protein sequence of the Lde pump was found to be $44 \%$ similar to that of PmrA of Streptococcus pneumoniae, a secondary multidrug transporter of the major facilitator superfamily (MFS). Evidence from another study also suggests that the Lde efflux pump contributes to ciprofloxacin resistance in L. monocytogenes [78]. In the same study, minimum inhibitory concentrations (MICs) of the disinfectant benzalkonium chloride (BC) were unaffected by the absence of the lde gene, indicating that the Lde efflux pump may not confer BC resistance. An earlier study had reported that both the Lde and the MdrL efflux pumps may confer BC resistance to L. monocytogenes, alongside other mechanisms [79]. Increased L. monocytogenes tolerance to $B C$ can be a result of the expression of an EmrE efflux pump [80]. The MdrL efflux pump is in charge of the extrusion of antimicrobial agents and heavy metals from the pathogen [81]. The MdrM and MdrT efflux pumps enable persistence and replication of the pathogen within the gastrointestinal tract, counteracting the bactericidal effects of mammalian bile [82]. The bile component cholic acid induces the expression of both pumps, but MdrT regulates the extrusion of cholic acid, which can be lethal to mutant strains lacking the MdrT efflux pump [83].

\subsection{Environmental Stress Exposure}

Listeria species may encounter sublethal concentrations of antimicrobial agents and growth inhibitors, e.g., bacteriocins and disinfectants (biocides) in the food processing and agriculture industries [84]. Such exposure may trigger adaptation to resist higher concentrations of these antimicrobials. Pre-exposure adaptation subsequently contributes to antibiotic resistance of Listeria species [15]. Co-selection for antibiotic resistance of Listeria species resulting from the use of biocides and heavy metals is reportedly a general concern [85]. One study reported significant correlations between biocide tolerance and antibiotic resistance in Listeria among other bacterial species isolated from seafood [86]. Unlimited exposure of the pathogen to sublethal dosages of chlorine may indirectly induce a significant tolerance to antibiotics, due to alterations in cell structure and morphology [87]. The bacteriocin nisin produced by Lactococcus lactis is one of the antimicrobial agents commonly applied in the food processing industry. However, nisin resistance by L. monocytogenes has been reported [88]. Nisin targets cell wall biosynthesis and cell membrane disruption, thus resistance may arise from alterations in the cell wall composition, hindering bacteriocin entry into the cell [89].

L. monocytogenes encounters environmental stresses in the food processing chain, and these stresses are usually effects of the numerous food preservation methods such as high salinity and acidic $\mathrm{pH}$ [90]. Adaptation of the pathogen to these sublethal stressful environmental conditions has been reported to contribute to antimicrobial resistance [91]. This is usually a result of bacterial phenotypic changes, mainly affecting cell wall and membrane structures, or alterations in efflux pump activity [92].

\section{Environmental Stress Adaptation}

\subsection{Acidity}

Acid tolerance response (ATR), arginine deiminase (ADI), and the glutamate decarboxylase (GAD) system are the three mechanisms employed by L. monocytogenes for persistence in low $\mathrm{pH}$ environments [93,94]. The ATR system is activated by pre-exposure to sublethal $\mathrm{pH}(5-6)$ and facilitates the pathogen's endurance in highly acidic settings [95]. The two-component pathway also protects the pathogen from osmotic stress and high temperatures [2].

The ADI system is operated by three enzymes: arginine deiminase hydrolyzes arginine to citrulline and ammonia, ornithine carbamoyltransferase catalyzes the conversion of citrulline to ammonia and carbamoylphospate, and carbamate kinase synthesizes ATP using carbamoylphosphate and adenosine diphosphate (ADP) [94]. The GAD system promotes the survival and growth of the pathogen in mild and extremely acidic environments [96]. It also enhances its passage through the stomach (gastric environment), enabling access to and invasion of the intestinal epithelial cells. Under extremely acidic 
conditions, the enzyme glutamate decarboxylase (encoded by gadA or gadB) decarboxylates imported extracellular glutamic acid to $\gamma$-aminobutyrate (GABA), consuming intracellular proteins [97].

Another mechanism for acid tolerance is the F0F1-ATPase complex. The F0F1-ATPase enzyme has two different domains: a cytoplasmic catalytic portion $\left(\mathrm{F}_{1}\right)$ responsible for ATP synthesis or hydrolysis and the integral membrane domain $\left(\mathrm{F}_{0}\right)$, functioning as a proton channel [98]. The enzyme synthesizes ATP aerobically using protons passing into the cell cytoplasm (oxidative phosphorylation) or hydrolyzes ATP as protons exit the cell, generating a proton motive force (PMF) [99].

\subsection{Osmotic Stress}

L. monocytogenes is reportedly capable of withstanding high salt concentrations $(\mathrm{NaCl})$ [100]. In response to osmotic stress, the pathogen activates two different mechanisms: the primary and the secondary responses. During the primary response, there is an influx of potassium cations and glutamate into the cell [89]. Uptake of osmoprotectants such as glycine betaine and carnitine follows [101]. Both mechanisms also assist the bacterium in maintaining turgidity and help in the stabilization of protein structure and function [102]. Two genes (lmo1078 and lmo2085) are responsible for cell envelop modification as an adaptation to osmotic stress [103,104]. A glucose phosphorylase, lmo1078, synthesizes UDP-glucose, the building unit of membrane glycolipids and the cell wall [103]. Imo2085 is an exterior protein covalently bound to cell wall peptidoglycans [104]. General stress response proteins are also expressed in response to osmotic shock, and in the absence of osmoprotectants, the protein Ctc, which confers high osmolarity resistance, is expressed [105].

\subsection{Low Temperatures (Cold Stress)}

Adaptation of L. monocytogenes to low temperatures involves the expression of cold shock proteins (CSPs) [106]. These are small proteins which assume the role of molecular chaperones, enabling replication, transcription, translation, and protein folding at low temperatures [107]. Another adaptation mechanism is the importation of glycine betaine and carnitine as cryoprotectants [90]. Increased intracellular solutes levels help reduce the loss of intracellular water in times of low temperatures [89]. In one investigation, a mutant L. monocytogenes strain for glycine betaine and carnitine uptake systems failed to accumulate or transport any of the two and, thus, it could not survive at low temperatures [108]. L. monocytogenes also alter its membrane structure at low temperatures. The membrane's rigidity increases due to an upsurge in the concentration of unsaturated fatty acids [109]. This prevents the development of a gel-like structure which may allow leakage of the cytoplasmic content [110].

\subsection{Oxidative Stress}

Oxidative stress arises from exposure to ROS (superoxide, hydroxyl radicals, and hydrogen peroxide) which may be generated during food processing [111]. Adaptations to oxidative stress includes ROS detoxification systems such as catalase (Cat), superoxide dismutase (Sod), and alkyl hydroperoxidase (AhpCF) [112]. Ferritin-like protein (fri) reportedly protects L. monocytogenes from the oxidative effects of hydrogen peroxide [113].

\section{Conclusions}

L. monocytogenes undoubtedly remains a foodborne pathogen of public health concern, owing to the high mortality and hospitalization rates caused by its infection [73]. The 2017-2018 listeriosis outbreak in South Africa was a clear evidence that, despite the development of treatments and biocontrol agents to combat L. monocytogenes, the pathogen remains a threat to food safety [114]. This is further worsened by the increasing tolerance of the pathogen to biocontrol agents and antimicrobials. Environmental stresses also have an impact on the pathogen's physiology, morphology, pathogenicity, gene expression, and antimicrobial resistance [91]. Understanding the pathogen's virulence, antimicrobial resistance mechanisms, and environmental stress adaptation will significantly contribute to the development of novel efficient, cost-effective antimicrobial agents and biocontrol methods for combating the pathogen. 
Continuous monitoring, stringent surveillance, and source tracking are also crucial for the detection of the pathogen's antimicrobial resistance developments [15].

Author Contributions: L.T.M. conducted the literature search and prepared the original manuscript. A.I.O. provided the conceptualization, reviewing, editing, supervision, and sourced the funding. All authors have read and agreed to the published version of the manuscript.

Funding: This research was funded by the South African Medical Research Council (Grant number: SAMRC/UFH/P790).

Acknowledgments: The authors are grateful to the South African Medical Research Council for financial support.

Conflicts of Interest: The authors declare no conflict of interest.

\section{References}

1. Volokhov, D.; Rasooly, A.; Chumakov, K.; Chizhikov, V. Identification of Listeria Species by Microarray-Based Assay. J. Clin. Microbiol. 2002, 40, 4720-4728. [CrossRef]

2. Davis, M.L.; Ricke, S.C.; Donaldson, J.R. Establishment of Listeria monocytogenes in the Gastrointestinal Tract. Microorganisms 2019, 7, 75. [CrossRef] [PubMed]

3. Pereira, S.A.; Alves, A.; Ferreira, V.; Teixeira, C.M. The Impact of Environmental Stresses in the Virulence Traits of Listeria monocytogenes Relevant to Food Safety. In Listeria monocytogenes; IntechOpen: Rijeka, Croatia, 2018; pp. 1-21.

4. David, D.J.V.; Cossart, P. Recent advances in understanding Listeria monocytogenes infection: The importance of subcellular and physiological context. F1000Research 2017, 6, F1000 Faculty Rev-1126. [CrossRef] [PubMed]

5. Allen, K.J.; Wałecka-Zacharska, E.; Chen, J.C.; Katarzyna, K.-P.; Devlieghere, F.; Van Meervenne, E.; Osek, J.; Wieczorek, K.; Bania, J. Listeria monocytogenes-An examination of food chain factors potentially contributing to antimicrobial resistance. Food Microbiol. 2016, 54, 178-189. [CrossRef]

6. Iwu, C.D.; Okoh, A.I. Characterization of antibiogram fingerprints in Listeria monocytogenes recovered from irrigation water and agricultural soil samples. PLoS ONE 2020, 15, e0228956. [CrossRef]

7. Cossart, P.; Archambaud, C. The bacterial pathogen Listeria monocytogenes: An emerging model in prokaryotic transcriptomics. J. Biol. 2009, 8, 107. [CrossRef]

8. Desai, A.N.; Anyoha, A.; Madoff, L.C.; Lassmann, B. Changing epidemiology of Listeria monocytogenes outbreaks, sporadic cases, and recalls globally: A review of ProMED reports from 1996 to 2018. Int. J. Infect. Dis. 2019, 84, 48-53. [CrossRef]

9. Ramaswamy, V.; Cresence, V.M.; Rejitha, J.S.; Lekshmi, M.U.; Dharsana, K.S.; Prasad, S.P.; Vijila, H.M. Listeria—Review of epidemiology and pathogenesis. J. Microbiol. Immunol. Infect. 2007, 40, 4-13.

10. Danion, F.; Maury, M.M.; Leclercq, A.; Moura, A.; Perronne, V.; Léotard, S.; Dary, M.; Tanguy, B.; Bracq-Dieye, H.; Thouvenot, P.; et al. Listeria monocytogenes isolation from urine: A series of 15 cases and review. Clin. Microbiol. Infect. 2017, 23, 583-585. [CrossRef]

11. Kurpas, M.; Wieczorek, K.; Osek, J. Ready-to-eat Meat Products as a Source of Listeria monocytogenes. J. Vet. Res. 2018, 62, 49-55. [CrossRef]

12. Iwu, D.C.; Okoh, I.A. Preharvest Transmission Routes of Fresh Produce Associated Bacterial Pathogens with Outbreak Potentials: A Review. Int. J. Environ. Res. Public Health 2019, 16, 4407. [CrossRef] [PubMed]

13. Dufour, C. Application of EC regulation no. 2073/2005 regarding Listeria monocytogenes in ready-to-eat foods in retail and catering sectors in Europe. Food Control. 2011, 22, 1491-1494. [CrossRef]

14. Lakicevic, B.; Nastasijevic, I. Listeria monocytogenes in retail establishments: Contamination routes and control strategies. Food Rev. Int. 2017, 33, 247-269. [CrossRef]

15. Olaimat, A.N.; Al-holy, M.A.; Shahbaz, H.M.; Al-nabulsi, A.A.; Abu Ghoush, M.H.; Osaili, T.M.; Ayyash, M.M.; Holley, R.A. Emergence of Antibiotic Resistance in Listeria monocytogenes Isolated from Food Products: A Comprehensive Review. Compr. Rev. Food Sci. Food Saf. 2018, 17, 1277-1292. [CrossRef]

16. Lungu, B.; Ricke, S.C.; Johnson, M.G. Growth, survival, proliferation and pathogenesis of Listeria monocytogenes under low oxygen or anaerobic conditions: A review. Anaerobe 2009, 15, 7-17. [CrossRef] [PubMed]

17. Va'Zquez-Boland, J.; Kuhn, M.; Berche, P.; Chakraborty, T.; Domi'Nguez-Bernal, G.; Goebel, W.; Gonzalez-Zorn, B.; Wehland, J.; Kreft, J. Listeria Pathogenesis and Molecular Virulence Determinants. Clin. Microbiol. Rev. 2001, 14, 584-640. [CrossRef] 
18. Farber, J.M.; Peterkin, P.I. Listeria monocytogenes, a Food-Borne Pathogen. Mcrobiol. Rev. 1991, 55, 476-511. [CrossRef]

19. Osborne, S.E.; Brumell, J.H. Listeriolysin O: From bazooka to Swiss army knife. Philos. Trans. R Soc. $B$ Biol. Sci. 2017, 372, 20160222. [CrossRef]

20. Vadia, S.; Arnett, E.; Haghighat, A.-C.; Wilson-Kubalek, E.M.; Tweten, R.K.; Seveau, S. The pore-forming toxin listeriolysin O mediates a novel entry pathway of L. monocytogenes into human hepatocytes. PLoS Pathog. 2011, 7, e1002356. [CrossRef]

21. Dramsi, S.; Cossart, P. Listeriolysin O-Mediated Calcium Influx Potentiates Entry of Listeria monocytogenes into the Human Hep-2 Epithelial Cell Line. Infect. Immun. 2003, 71, 3614-3618. [CrossRef]

22. Carrero, J.A.; Calderon, B.; Unanue, E.R. Listeriolysin O from Listeria monocytogenes Is a Lymphocyte Apoptogenic Molecule. J. Immunol. 2004, 172, 4866-4874. [CrossRef] [PubMed]

23. Maury, M.M.; Chenal-Francisque, V.; Bracq-Dieye, H.; Han, L.; Leclercq, A.; Vales, G.; Moura, A.; Gouin, E.; Scortti, M.; Disson, O.; et al. Spontaneous Loss of Virulence in Natural Populations of Listeria monocytogenes. Infect. Immun. 2017, 85, e00541-17. [CrossRef] [PubMed]

24. Lam, G.Y.; Fattouh, R.; Muise, A.M.; Grinstein, S.; Higgins, D.E.; Brumell, J.H. Listeriolysin O Suppresses Phospholipase C-Mediated Activation of the Microbicidal NADPH Oxidase to Promote Listeria monocytogenes Infection. Cell Host Microbe 2011, 10, 627-634. [CrossRef] [PubMed]

25. Hamon, M.A.; Batsché, E.; Régnault, B.; Tham, T.N.; Seveau, S.; Muchardt, C.; Cossart, P. Histone modifications induced by a family of bacterial toxins. Proc. Natl. Acad. Sci. USA 2007, 104, 13467-13472. [CrossRef] [PubMed]

26. Malet, J.K.; Impens, F.; Carvalho, F.; Hamon, M.A.; Cossart, P.; Ribet, D. Rapid Remodeling of the Host Epithelial Cell Proteome by the Listeriolysin O (LLO) Pore-forming Toxin. Mol. Cell. Proteom. 2018, 17, 1627-1636. [CrossRef]

27. Stavru, F.; Bouillaud, F.; Sartori, A.; Ricquier, D.; Cossart, P. Listeria monocytogenes transiently alters mitochondrial dynamics during infection. Proc. Natl. Acad. Sci. USA 2011, 108, 3612-3617. [CrossRef]

28. Schnupf, P.; Portnoy, D.A. Listeriolysin O: A phagosome-specific lysin. Microbes Infect. 2007, 9, $1176-1187$. [CrossRef]

29. Hamon, M.A.; Ribet, D.; Stavru, F.; Cossart, P. Listeriolysin O: The Swiss army knife of Listeria. Trends Microbiol. 2012, 20, 360-368. [CrossRef]

30. Schuerch, D.W.; Wilson-Kubalek, E.M.; Tweten, R.K. Molecular basis of listeriolysin O pH dependence. Proc. Natl. Acad. Sci. USA 2005, 102, 12537-12542. [CrossRef]

31. Smith, G.A.; Marquis, H.; Jones, S.; Johnston, N.C.; Portnoy, D.A.; Goldfine, H. The two distinct phospholipases $\mathrm{C}$ of Listeria monocytogenes have overlapping roles in escape from a vacuole and cell-to-cell spread. Infect. Immun. 1995, 63, 4231-4237. [CrossRef]

32. Camilli, A.; Tilney, L.G.; Portnoy, D.A. Dual roles of plcA in Listeria monocytogenes pathogenesis. Mol. Microbiol. 1993, 8, 143-157. [CrossRef] [PubMed]

33. Alberti-Segui, C.; Goeden, K.R.; Higgins, D.E. Differential function of Listeria monocytogenes listeriolysin O and phospholipases $C$ in vacuolar dissolution following cell-to-cell spread. Cell. Microbiol. 2007, 9, 179-195. [CrossRef] [PubMed]

34. Tattoli, I.; Sorbara, M.T.; Yang, C.; Tooze, S.A.; Philpott, D.J.; Girardin, S.E. Listeria phospholipases subvert host autophagic defenses by stalling pre-autophagosomal structures. EMBO J. 2013, 32, 3066-3078. [CrossRef]

35. Tattoli, I.; Sorbara, M.T.; Philpott, D.J.; Girardin, S.E. Bacterial autophagy: The trigger, the target and the timing. Autophagy 2012, 8, 1848-1850. [CrossRef] [PubMed]

36. Birmingham, C.L.; Canadien, V.; Gouin, E.; Troy, E.B.; Cossart, P.; Higgins, D.E.; Brumell, J.H. Listeria monocytogenes Evades Killing by Autophagy during Colonization of Host Cells. Autophagy 2007, 3, 442-451. [CrossRef] [PubMed]

37. Yeung, P.S.M.; Zagorski, N.; Marquis, H. The Metalloprotease of Listeria monocytogenes Controls Cell Wall Translocation of the Broad-Range Phospholipase C. J. Bacteriol. 2005, 187, 2601-2608. [CrossRef] [PubMed]

38. Gründling, A.; Gonzalez, M.D.; Higgins, D.E. Requirement of the Listeria monocytogenes broad-range phospholipase PC-PLC during infection of human epithelial cells. J. Bacteriol. 2003, 185, 6295-6307. [CrossRef]

39. Montes, L.-R.; Goñi, F.M.; Johnston, N.C.; Goldfine, H.; Alonso, A. Membrane Fusion Induced by the Catalytic Activity of a Phospholipase C/Sphingomyelinase from Listeria monocytogenes. Biochemistry 2004, 43, 3688-3695. [CrossRef] 
40. Schlüter, D.; Domann, E.; Buck, C.; Hain, T.; Hof, H.; Chakraborty, T.; Deckert-Schlüter, M. Phosphatidylcholinespecific phospholipase $\mathrm{C}$ from Listeria monocytogenes is an important virulence factor in murine cerebral listeriosis. Infect. Immun. 1998, 66, 5930-5938. [CrossRef]

41. Marquis, H.; Hager, E.J. pH-regulated activation and release of a bacteria-associated phospholipase C during intracellular infection by Listeria monocytogenes. Mol. Microbiol. 2000, 35, 289-298. [CrossRef]

42. Blank, B.S.; Abi Abdallah, D.S.; Park, J.J.; Nazarova, E.V.; Pavinski Bitar, A.; Maurer, K.J.; Marquis, H. Misregulation of the broad-range phospholipase C activity increases the susceptibility of Listeria monocytogenes to intracellular killing by neutrophils. Microbes Infect. 2014, 16, 104-113. [CrossRef] [PubMed]

43. Yeung, P.S.M.; Na, Y.; Kreuder, A.J.; Marquis, H. Compartmentalization of the Broad-Range Phospholipase C Activity to the Spreading Vacuole Is Critical for Listeria monocytogenes Virulence. Infect. Immun. 2007, 75, 44-51. [CrossRef] [PubMed]

44. Poussin, M.A.; Goldfine, H. Evidence for the involvement of ActA in maturation of the Listeria monocytogenes phagosome. Cell Res. 2009, 20, 109-112. [CrossRef] [PubMed]

45. Yoshikawa, Y.; Ogawa, M.; Hain, T.; Chakraborty, T.; Sasakawa, C. Listeria monocytogenes ActA is a key player in evading autophagic recognition. Autophagy 2009, 5, 1220-1221. [CrossRef] [PubMed]

46. Le Monnier, A.; Autret, N.; Join-lambert, O.F.; Jaubert, F.; Charbit, A.; Berche, P.; Kayal, S. ActA Is Required for Crossing of the Fetoplacental Barrier by Listeria monocytogenes. Infect. Immun. 2007, 75, 950-957. [CrossRef]

47. Travier, L.; Guadagnini, S.; Gouin, E.; Dufour, A.; Chenal-Francisque, V.; Cossart, P.; Olivo-Marin, J.; Ghigo, J.; Disson, O.; Lecuit, M. ActA Promotes Listeria monocytogenes Aggregation, Intestinal Colonization and Carriage. PLoS Pathog. 2013, 9, e1003131. [CrossRef]

48. Cheng, M.I.; Chen, C.; Engström, P.; Portnoy, D.A.; Mitchell, G. Actin-based motility allows Listeria monocytogenes to avoid autophagy in the macrophage cytosol. Cell. Microbiol. 2018, 20, e12854. [CrossRef]

49. Bonazzi, M.; Lecuit, M.; Cossart, P. Listeria monocytogenes internalin and E-cadherin: From bench to bedside. Cold Spring Harb. Perspect. Biol. 2009, 1, a003087. [CrossRef]

50. Bierne, H.; Sabet, C.; Personnic, N.; Cossart, P. Internalins: A complex family of leucine-rich repeat-containing proteins in Listeria monocytogenes. Microbes Infect. 2007, 9, 1156-1166. [CrossRef]

51. Bierne, H.; Cossart, P. InlB, a surface protein of Listeria monocytogenes that behaves as an invasin and a growth factor. J. Cell Sci. 2002, 115, 3357-3367.

52. Quereda, J.J.; Rodríguez-Gómez, I.M.; Meza-Torres, J.; Gómez-Laguna, J.; Nahori, M.A.; Dussurget, O.; Carrasco, L.; Cossart, P.; Pizzaro-Cerda, J. Reassessing the role of internalin B in Listeria monocytogenes virulence using the epidemic strain F2365. Clin. Microbiol. Infect. 2019, 25, 252.e1-252.e4. [CrossRef]

53. Seveau, S.; Pizarro-Cerda, J.; Cossart, P. Molecular mechanisms exploited by Listeria monocytogenes during host cell invasion. Microbes Infect. 2007, 9, 1167-1175. [CrossRef]

54. Lecuit, M.; Ohayon, H.; Braun, L.; Mengaud, J.; Cossart, P. Internalin of Listeria monocytogenes with an intact leucine-rich repeat region is sufficient to promote internalization. Infect. Immun. 1997, 65, 5309-5319. [CrossRef]

55. Marino, M.; Braun, L.; Cossart, P.; Ghosh, P. A framework for interpreting the leucine-rich repeats of the Listeria internalins. Proc. Natl. Acad. Sci. USA 2000, 97, 8784-8788. [CrossRef] [PubMed]

56. Popowska, M.; Krawczyk-Balska, A.; Ostrowski, R.; Desvaux, M. InlL from Listeria monocytogenes Is Involved in Biofilm Formation and Adhesion to Mucin. Front. Microbiol. 2017, 8, 660. [CrossRef] [PubMed]

57. Loo, K.Y.; Letchumanan, V.; Dhanoa, A.; Law, W.; Pusparajah, P.; Goh, B.; Ser, H.; Wong, S.H.; Mutalib, N.A.; Chan, K.; et al. Exploring the Pathogenesis, Clinical Characteristics and Therapeutic Regimens of Listeria monocytogenes. Acta Sci. Microbiol. 2020, 3. [CrossRef]

58. Harter, E.; Lassnig, C.; Wagner, E.M.; Zaiser, A.; Wagner, M.; Rychli, K. The Novel Internalins InlP1 and InlP4 and the Internalin-Like Protein InlP3 Enhance the Pathogenicity of Listeria monocytogenes. Front. Microbiol. 2019, 10, 1644. [CrossRef]

59. Evans, R.P., Jr.; Macrina, F.L. Streptococcal R plasmid pIP501: Endonuclease site map, resistance determinant location, and construction of novel derivatives. J. Bacteriol. 1983, 154, 1347-1355. [CrossRef]

60. Charpentier, E.; Courvalin, P. Antibiotic resistance in Listeria spp. Antimicrob. Agents Chemother. 1999, 43, 2103-2108. [CrossRef]

61. Vicente, M.F.; Baquero, F.; Pérez-Diaz, J.C. Conjugative acquisition and expression of antibiotic resistance determinants in Listeria spp. J. Antimicrob. Chemother. 1988, 21, 309-318. [CrossRef] 
62. Flamm, R.K.; Hinrichs, D.J.; Thomashow, M.F. Introduction of pAM beta 1 into Listeria monocytogenes by conjugation and homology between native L. monocytogenes plasmids. Infect. Immun. 1984, 44, 157-161. [CrossRef] [PubMed]

63. Guglielmetti, E.; Korhonen, J.M.; Heikkinen, J.; Morelli, L.; Von Wright, A. Transfer of plasmid-mediated resistance to tetracycline in pathogenic bacteria from fish and aquaculture environments. FEMS Microbiol. Lett. 2009, 293, 28-34. [CrossRef]

64. Celli, J.; Trieu-Cuot, P. Circularization of Tn916 is required for expression of the transposon-encoded transfer functions: Characterization of long tetracycline-inducible transcripts reading through the attachment site. Mol. Microbiol. 1998, 28, 103-117. [CrossRef]

65. Perreten, V.; Kollöffel, B.; Teuber, M. Conjugal Transfer of the Tn916-like Transposon TnFO1 from Enterococcus faecalis Isolated from Cheese to Other Gram-positive Bacteria. Syst. Appl. Microbiol. 1997, 20, 27-38. [CrossRef]

66. Luque-sastre, L.; Arroyo, C.; Fox, E.M.; Mcmahon, B.J.; Bai, L.I.; Li, F.; Fanning, S. Antimicrobial Resistance in Listeria Species. Microbiol. Spectr. 2018, 6, 237-259.

67. Bertrand, S.; Huys, G.; Yde, M.; D’Haene, K.; Tardy, F.; Vrints, M.; Swings, J.; Collard, J. Detection and characterization of tet $(\mathrm{M})$ in tetracycline-resistant Listeria strains from human and food-processing origins in Belgium and France. J. Med Microbiol. 2005, 54, 1151-1156. [CrossRef]

68. Knudsen, G.M.; Ng, Y.; Gram, L. Survival of Bactericidal Antibiotic Treatment by a Persister Subpopulation of Listeria monocytogenes. Appl. Environ. Microbiol. 2013, 79, 7390-7397. [CrossRef]

69. Wen, J.; Deng, X.; Li, Z.; Dudley, E.G.; Anantheswaran, R.C.; Knabel, S.J.; Zhang, W. Transcriptomic Response of Listeria monocytogenes during the Transition to the Long-Term-Survival Phase. Appl. Environ. Microbiol. 2011, 77, 5966-5972. [CrossRef]

70. Wood, T.K.; Knabel, S.J.; Kwan, B.W. Bacterial Persister Cell Formation and Dormancy. Appl. Environ. Microbiol. 2013, 79, 7116-7121. [CrossRef]

71. Lee, B.-H.; Hébraud, M.; Bernardi, T. Increased Adhesion of Listeria monocytogenes Strains to Abiotic Surfaces under Cold Stress. Front. Microbiol. 2017, 8, 2221. [CrossRef]

72. da Silva, E.P.; De Martinis, E.C.P. Current knowledge and perspectives on biofilm formation: The case of Listeria monocytogenes. Appl. Microbiol. Biotechnol. 2013, 97, 957-968. [CrossRef]

73. Gray, J.A.; Chandry, P.S.; Kaur, M.; Kocharunchitt, C.; Bowman, J.P.; Fox, E.M. Novel Biocontrol Methods for Listeria monocytogenes Biofilms in Food Production Facilities. Front. Microbiol. 2018, 9, 605. [CrossRef]

74. Borucki, M.K.; Peppin, J.D.; White, D.; Loge, F.; Call, D.R. Variation in Biofilm Formation among Strains of Listeria monocytogenes. Appl. Environ. Microbiol. 2003, 69, 7336-7342. [CrossRef]

75. Yoon, Y.; Lee, H.; Lee, S.; Kim, S.; Choi, K.-H. Membrane fluidity-related adaptive response mechanisms of foodborne bacterial pathogens under environmental stresses. Food Res. Int. 2015, 72, 25-36. [CrossRef]

76. Oxaran, V.; Dittmann, K.K.; Lee, S.H.I.; Chaul, L.T.; Fernandes de Oliveira, C.A.; Corassin, C.H.; Alves, V.F.; Pereira De Martinis, E.C.; Gram, L. Behavior of Foodborne Pathogens Listeria monocytogenes and Staphylococcus aureus in Mixed-Species Biofilms Exposed to Biocides. Appl. Environ. Microbiol. 2018, 84, e02038-18. [CrossRef]

77. Godreuil, S.; Galimand, M.; Gerbaud, G.; Jacquet, C.; Courvalin, P. Efflux pump Lde is associated with fluoroquinolone resistance in Listeria monocytogenes. Antimicrob. Agents Chemother. 2003, 47, 704-708. [CrossRef]

78. Jiang, X.; Yu, T.; Xu, P.; Xu, X.; Ji, S.; Gao, W.; Shi, L. Role of Efflux Pumps in the in vitro Development of Ciprofloxacin Resistance in Listeria monocytogenes. Front. Microbiol. 2018, 9, 2350. [CrossRef]

79. Romanova, N.A.; Wolffs, P.F.G.; Brovko, L.Y.; Griffiths, M.W. Role of efflux pumps in adaptation and resistance of Listeria monocytogenes to benzalkonium chloride. Appl. Environ. Microbiol. 2006, 72, 3498-3503. [CrossRef]

80. Kovacevic, J.; Ziegler, J.; Wałecka-Zacharska, E.; Reimer, A.; Kitts, D.D.; Gilmour, M.W. Tolerance of Listeria monocytogenes to Quaternary Ammonium Sanitizers Is Mediated by a Novel Efflux Pump Encoded by emrE. Appl. Environ. Microbiol. 2016, 82, 939-953. [CrossRef]

81. Mata, M.T.; Baquero, F.; Pérez-Díaz, J.C. A multidrug efflux transporter in Listeria monocytogenes. FEMS Microbiol. Lett. 2000, 187, 185-188. [CrossRef]

82. Quillin, S.J.; Schwartz, K.T.; Leber, J.H. The novel Listeria monocytogenes bile sensor BrtA controls expression of the cholic acid efflux pump MdrT. Mol. Microbiol. 2011, 81, 129-142. [CrossRef] [PubMed]

83. Alcalde-Rico, M.; Hernando-Amado, S.; Blanco, P.; Martínez, J.L. Multidrug Efflux Pumps at the Crossroad between Antibiotic Resistance and Bacterial Virulence. Front. Microbiol. 2016, 7, 1483. [CrossRef] [PubMed] 
84. Rodríguez-López, P.; Rodríguez-Herrera, J.J.; Vázquez-Sánchez, D.; Lopez Cabo, M. Current Knowledge on Listeria monocytogenes Biofilms in Food-Related Environments: Incidence, Resistance to Biocides, Ecology and Biocontrol. Foods 2018, 7, 85. [CrossRef] [PubMed]

85. Wales, D.A.; Davies, H.R. Co-Selection of Resistance to Antibiotics, Biocides and Heavy Metals, and Its Relevance to Foodborne Pathogens. Antibiotics 2015, 4, 567-604. [CrossRef]

86. Romero, J.L.; Grande Burgos, M.J.; Pérez-Pulido, R.; Gálvez, A.; Lucas, R. Resistance to Antibiotics, Biocides, Preservatives and Metals in Bacteria Isolated from Seafoods: Co-Selection of Strains Resistant or Tolerant to Different Classes of Compounds. Front. Microbiol. 2017, 8, 1650. [CrossRef]

87. Bansal, M.; Nannapaneni, R.; Sharma, C.S.; Kiess, A. Listeria monocytogenes Response to Sublethal Chlorine Induced Oxidative Stress on Homologous and Heterologous Stress Adaptation. Front. Microbiol. 2018, 9 , 2050. [CrossRef]

88. Gravesen, A.; Jydegaard Axelsen, A.M.; Mendes da Silva, J.; Hansen, T.B.; Knøchel, S. Frequency of Bacteriocin Resistance Development and Associated Fitness Costs in Listeria monocytogenes. Appl. Environ. Microbiol. 2002, 68, 756-764. [CrossRef]

89. NicAogáin, K.; O'Byrne, C.P. The Role of Stress and Stress Adaptations in Determining the Fate of the Bacterial Pathogen Listeria monocytogenes in the Food Chain. Front. Microbiol. 2016, 7, 1865. [CrossRef]

90. Bucur, F.I.; Grigore-Gurgu, L.; Crauwels, P.; Riedel, C.U.; Nicolau, A.I. Resistance of Listeria monocytogenes to Stress Conditions Encountered in Food and Food Processing Environments. Front. Microbiol. 2018, 9, 2700. [CrossRef]

91. Lungu, B.; Group, A.; Milillo, S.R.; Johnson, M.G.; Crandall, P.G.; Ricke, S.C. Listeria monocytogenes: Antibiotic Resistance in Food Production. Foodborne Pathog. Dis. 2011, 8, 569-578. [CrossRef]

92. Reygaert, W.C. An overview of the antimicrobial resistance mechanisms of bacteria. AIMS Microbiol. 2018, 4, 482-501. [CrossRef] [PubMed]

93. Smith, J.L.; Liu, Y.; Paoli, G.C. How does Listeria monocytogenes combat acid conditions? Can. J. Microbiol. 2012, 59, 141-152. [CrossRef] [PubMed]

94. Ryan, S.; Begley, M.; Gahan, C.; Hill, C. Molecular characterization of the arginine deiminase system in Listeria monocytogenes: Regulation and role in acid tolerance. Environ. Microbiol. 2009, 11, 432-445. [CrossRef] [PubMed]

95. Chorianopoulos, N.; Giaouris, E.; Grigoraki, I.; Skandamis, P.; Nychas, G.-J. Effect of acid tolerance response (ATR) on attachment of Listeria monocytogenes Scott A to stainless steel under extended exposure to acid or/and salt stress and resistance of sessile cells to subsequent strong acid challenge. Int. J. Food Microbiol. 2011, 145, 400-406. [CrossRef]

96. Karatzas, K.-A.G.; Suur, L.; O’Byrne, C.P. Characterization of the intracellular glutamate decarboxylase system: Analysis of its function, transcription, and role in the acid resistance of various strains of Listeria monocytogenes. Appl. Environ. Microbiol. 2012, 78, 3571-3579. [CrossRef] [PubMed]

97. Feehily, C.; Finnerty, A.; Casey, P.G.; Hill, C.; Gahan, C.G.M.; O’Byrne, C.P.; Karatzas, K.G. Divergent Evolution of the Activity and Regulation of the Glutamate Decarboxylase Systems in Listeria monocytogenes EGD-e and 10403S: Roles in Virulence and Acid Tolerance. PLoS ONE 2014, 9, e112649. [CrossRef]

98. Cotter, P.D.; Gahan, C.G.M.; Hill, C. Analysis of the role of the Listeria monocytogenes F0F1-ATPase operon in the acid tolerance response. Int. J. Food Microbiol. 2000, 60, 137-146. [CrossRef]

99. Cotter, P.D.; Hill, C. Surviving the Acid Test: Responses of Gram-Positive Bacteria to Low pH. Microbiol. Mol. Biol Rev. 2003, 67, 429-453. [CrossRef]

100. Shabala, L.; Lee, S.H.U.I.; Cannesson, P.; Ross, T.O.M. Acid and NaCl Limits to Growth of Listeria monocytogenes and Influence of Sequence of Inimical Acid and $\mathrm{NaCl}$ Levels on Inactivation Kinetics. J. Food Prot. 2008, 71, 1169-1177. [CrossRef]

101. Sleator, R.D.; Gahan, C.G.M.; Hill, C. A Postgenomic Appraisal of Osmotolerance in Listeria monocytogenes. Appl. Environ. Microbiol. 2003, 69, 1-9. [CrossRef]

102. Smiddy, M.; Sleator, R.D.; Patterson, M.F.; Hill, C.; Kelly, A.L. Role for Compatible Solutes Glycine Betaine and 1-Carnitine in Listerial Barotolerance. Appl. Environ. Microbiol. 2004, 70, 7555-7557. [CrossRef] [PubMed]

103. Chassaing, D.; Auvray, F. The lmo1078 gene encoding a putative UDP-glucose pyrophosphorylase is involved in growth of Listeria monocytogenes at low temperature. FEMS Microbiol. Lett. 2007, 275, 31-37. [CrossRef] [PubMed] 
104. Utratna, M.; Shaw, I.; Starr, E.; O’Byrne, C.P. Rapid, transient, and proportional activation of $\sigma(B)$ in response to osmotic stress in Listeria monocytogenes. Appl. Environ. Microbiol. 2011, 77, 7841-7845. [CrossRef] [PubMed]

105. Gardan, R.; Duché, O.; Leroy-Sétrin, S.; Labadie, J.; Consortium, E.L.G. Role of ctc from Listeria monocytogenes in osmotolerance. Appl. Environ. Microbiol. 2003, 69, 154-161. [CrossRef]

106. Schmid, B.; Klumpp, J.; Raimann, E.; Loessner, M.J.; Stephan, R.; Tasara, T. Role of Cold Shock Proteins in Growth of Listeria monocytogenes under Cold and Osmotic Stress Conditions. Appl. Environ. Microbiol. 2009, 75, 1621-1627. [CrossRef]

107. Eshwar, A.K.; Guldimann, C.; Oevermann, A.; Tasara, T. Cold-Shock Domain Family Proteins (Csps) Are Involved in Regulation of Virulence, Cellular Aggregation, and Flagella-Based Motility in Listeria monocytogenes. Front. Cell. Infect. Microbiol. 2017, 7, 453. [CrossRef]

108. Angelidis, A.S.; Smith, G.M. Role of the Glycine Betaine and Carnitine Transporters in Adaptation of Listeria monocytogenes to Chill Stress in Defined Medium. Appl. Environ. Microbiol. 2003, 69, 7492-7498. [CrossRef]

109. Neunlist, M.R.; Federighi, M.; Laroche, M.; Sohier, D.; Delattre, G.; Jacquet, C.; Chihib, N. Cellular Lipid Fatty Acid Pattern Heterogeneity between Reference and Recent Food Isolates of Listeria monocytogenes as a Response to Cold Stress. Antonie Van Leeuwenhoek 2005, 88, 199-206. [CrossRef]

110. Beales, N. Adaptation of Microorganisms to Cold Temperatures, Weak Acid Preservatives, Low $\mathrm{pH}$, and Osmotic Stress: A Review. Compr. Rev. Food Sci. Food Saf. 2004, 3, 1-20. [CrossRef]

111. Lobo, V.; Patil, A.; Phatak, A.; Chandra, N. Free radicals, antioxidants and functional foods: Impact on human health. Pharmacogn. Rev. 2010, 4, 118-126. [CrossRef]

112. Kocaman, N.; Sarimehmetoğlu, B. Stress responses of Listeria monocytogenes. Ankara Üniv. Vet. Fak. Derg. 2016, 63, 421-427.

113. Huang, Y.; Morvay, A.A.; Shi, X.; Suo, Y.; Shi, C.; Knøchel, S. Comparison of oxidative stress response and biofilm formation of Listeria monocytogenes serotypes $4 \mathrm{~b}$ and 1/2a. Food Control. 2018, 85, 416-422. [CrossRef]

114. Kayode, A.; Igbinosa, E.; Okoh, A.I. Overview of listeriosis in the Southern African Hemisphere-Review. J. Food Saf. 2020, 40, e12732. [CrossRef]

(C) 2020 by the authors. Licensee MDPI, Basel, Switzerland. This article is an open access article distributed under the terms and conditions of the Creative Commons Attribution (CC BY) license (http://creativecommons.org/licenses/by/4.0/). 